\title{
Extraction and Characterisation of Starches from Four Varieties of Mangifera indica Seeds
}

\author{
${ }^{1}$ L. G Hassan, ${ }^{1}$ A. B. Muhammad, ${ }^{2}$ R. U. Aliyu, ${ }^{3}$ Z. M. Idris, ${ }^{4}$ T. Izuagie, \\ ${ }^{1}$ K.J. Umar and ${ }^{1}$ N.A. Sani \\ ${ }^{I}$ Department of Pure and Applied Chemistry, Usmanu Danfodiyo University, Sokoto, Nigeria \\ ${ }^{2}$ Department of Biochemistry, Usmanu Danfodiyo University, Sokoto, Nigeria \\ ${ }^{3}$ Department of Science Laboratory Technology, Abdu Gusau Polytechnic, Talata-Mafara, Nigeria \\ ${ }^{4}$ Department of Natural Sciences, The Sokoto State Polytechnic, Sokoto, Nigeria
}

\begin{abstract}
Starch is widely used in the food and pharmaceutical industries for various applications. These industries often rely on crops that are also traditional sources of food by man resulting high demand with consequence economic implications. In this work starches from four varieties of mango (Mangifera indica) seeds were extracted and characterised using standard methods for potential industrial applications. The results showed that the average starch content of the seeds is $60.44 \pm 5.26 \%$ although there are statistically significant differences amongst the varieties. Moisture content $(6.23 \pm 1.36 \%)$, ash content $(0.158 \pm 0.101 \%)$, starch protein $(0.0669 \pm 0.0027 \%)$ and starch lipid $(0.208 \pm 0.0417 \%$, ) were low. Amylose content was within the range of $11.90-16.74 \%$. Swelling power $(19.40 \pm 0.30-19.80 \pm 0.36 \mathrm{~g} / \mathrm{g})$ and solubility $(0.135 \pm 0.002-0.142 \pm 0.001 \%)$ were less variable amongst the varieties. The Amylopectin content of the starches was within the range of $83.25 \pm 0.10-90.60 \pm 0.40 \%)$; and significant variations $(p<0.05)$ were observed amongst the mango varieties. It was also observed that the onset gelatinization temperature of the starches ranged from 60.5 to $63.4^{\circ} \mathrm{C}$ whereas the conclusion gelatinization temperature was from 70.2 to $73.4^{\circ} \mathrm{C}$. In general, even though there are significant differences in some of the properties of the starches, the starches show good properties and could serve as alternatives for the production of industrial products that may require starch.

Keywords: Seeds, Mango, Starch, Amylose, Amylopectin, gelatinization, Swelling power
\end{abstract}

\section{Introduction}

Starch is the predominant food reserve substance in plants. It is greatly in abundance and is readily converted into useful chemicals and products [1]. Thus, it finds application in many industries. The major sources of starch are: maize, wheat, rice, cassava, yam and potato [2]. Starches have also been extracted from other sources such as millet, Oat, sorghum, lentils, peas, etc. Recently, starches from seeds of fruits, which are usually discarded after eating the pulp, were also characterized. The starches were found to possess good physicochemical properties [3,4].

One seed that gave a very good starch was mango seed. Mango (Mangifera indica) is a fleshy stone fruit belonging to the genus Mangifera, consisting of numerous tropical fruiting trees in the flowering plant family Anacardiaceae. The mango tree is commonly cultivated in many tropical and subtropical regions, and it can grow up to $15-20 \mathrm{~m}$ high, and also its trunk can reach a diameter of $1.5 \mathrm{~m}$. The fruit is oval; round, heartshaped, kidney- shaped with varying sizes and bears one seed. It measures an average of $8-20 \mathrm{~cm}$ by $7-12 \mathrm{~cm}$. The seed can be hairy or fibrous. The ripe fruit varies in size and color. There are several cultivars, which are variously yellow, orange red, or green [5]. It has been cultivated in South Asia for thousands of years and reached East Asia and other regions between the fifth and fourth centuries BC. Mango is now cultivated in most frost-free tropical and warmer subtropical climates. The total world production in 2002 was put at $25,760,848$ Mt (FAO, 2002) and more than a third of the world's mangoes are cultivated in India alone [6-8]. There are over a thousand mango varieties around the world and the varieties grown in different regions have been described [8]. Several varieties are also found within Nigeria. It is against this background that this paper is aimed at isolating and characterising starches from four varieties of mango seeds commonly found in Sokoto State with a view to establishing if there is any significant difference in the properties of the starches from the different varieties of mango found within the region.

\section{Samples Collection and Preparation}

\section{Materials And Methods}

About 30 pieces each of four varieties of ripe mango cultivars locally called Bintasuga, Dankamaru, Paparanda and Peter in Hausa lnaguage were procured from a local market (Kasuwar Daji) in Sokoto metropolis, Sokoto State, Nigeria. Each variety was identified at the Department of Crop Science, Usmanu 
Danfodiyo University, Sokoto. The samples were washed and peeled to recover the seeds. The outer casings of the seeds were removed manually and the embryos were washed and directly subjected to starch extraction.

\section{Analyses of Samples \\ Total starch content determination}

Total starch content of the seeds was determined as described by Ezeagu et al. [9]. Briefly, soluble sugars were extracted with ethanol (95\%) and residual starch was then hydrolysed with perchloric acid into monosaccharides. The sugar was colorimetrically determined with phenol-sulphuric acid by means of a UV-VIS spectrophotometer (UVIKON 932,).

\section{Starch Isolation}

The recovered embryos of the samples were cut into small pieces and steeped in $0.16 \%$ aqueous solution of sodium hydrogen sulphite for $24 \mathrm{hrs}$ at $50^{\circ} \mathrm{C}$ for preservation. The solution was decanted, and the samples were ground in a laboratory blender. The ground slurry was screened through muslin cloth where it was left and washed thoroughly with distilled water. After $1 \mathrm{hr}$, the supernatant was decanted from the filtrate and the settled starch layer was re-suspended in distilled water and centrifuged at $2800 \mathrm{rpm}$ for $5 \mathrm{~min}$. The upper nonwhite layer of the residue was scraped off and the white layer was re-suspended in distilled water and centrifuged. This was repeated 4 more times and finally the starch was then collected and dried at $50^{\circ} \mathrm{C}$ for $6 \mathrm{hrs}$ in an oven [10].

\section{Proximate analysis of starch (a)Moisture Content Determination}

This was determined using the method described in Ezeagu et al. [9] and Lee et al. [11](2007).

\section{(b)Total Ash Determination}

Ash content was estimated by the measurement of the residue left after combustion of $2 \mathrm{~g}$ of starch in a silica dish at $450^{\circ} \mathrm{C}$ and the percentage of ash was calculated relative to the amount of sample combusted [12].

(c)Starch Protein Determination

This was done by first determining nitrogen content by the standard micro-Kjeldahl method using a digestion apparatus (Kjeldatherm System KT 40) and a titration system as described in AOAC [13].

\section{(d)Starch lipid Determination}

This was assayed by extraction of the lipid with petroleum ether (boiling point $40^{\circ}-60^{\circ} \mathrm{C}$ ) using a Soxhlet extractor as described in Ezeagu et al. [9].

\section{Amylose Content Determination}

This was determined by using the method of Williams et al. [14]. Briefly, $0.10 \mathrm{~g}$ of the sample was weighed into a $100 \mathrm{~cm}^{3}$ volumetric flask and $1 \mathrm{~cm}^{3}$ of $99 \%$ ethanol and $9 \mathrm{~cm}^{3}$ of $1 \mathrm{M}$ sodium hydroxide solution were carefully added. The contents were mixed thoroughly and the sample solution was heated for 10 mins in boiling water to gelatinize the starch. After cooling the solution was made up to the mark with distilled water and shaken thoroughly. Five (5) $\mathrm{cm}^{3}$ of the starch solution in a $100 \mathrm{~cm}^{3}$ volumetric flasks was treated with $1.0 \mathrm{~cm}^{3}$ of $1 \mathrm{M}$ acetic acid and $2.0 \mathrm{~cm}^{3}$ of iodine solution. The solution was diluted to the mark with distilled water And the absorbance was read using spectrophotometer at $620 \mathrm{~nm}$. Absorbance of blank solution prepared accordingly was subtracted from that of the sample and amylose and amylopectin contents were calculated using equations (1) and (2) respectively:

Amylose content $(\%)=3.06 \times$ absorbance $\mathrm{x} 20$

Amylopectin $(\%)=100-\%$ amylose content.

\section{Granular Morphology}

Granular morphology was determined using an optical microscope (S-0009). The starch sample was suspended in glycerol to ensure uniformity of the test sample. One drop of the suspension was placed on a slide glass and then viewed under microscope at magnification of x1000 [15].

\section{Gelatinization temperature determination}

A $0.29 \% \mathrm{w} / \mathrm{v}$ suspension of the sample in water in a $25 \mathrm{~cm}^{3}$ beaker was warmed in a water bath at $40^{\circ} \mathrm{C}$. The temperature was then gradually raised and after every $\sim 2^{\circ} \mathrm{C}$ a samples was withdrawn and observed under a polarized microscope. The temperature at which the granules completely lost their polarization crosseswas recorded as gelatinization temperature [16]. 


\section{Determination of swelling power and solubility}

The method of Nadiha et al. [17]) was used in the determination of swelling power and solubility. Briefly, $0.400 \mathrm{~g}$ of starch sample in a centrifuge tube was treated with $40 \mathrm{~cm}^{3}$ of distilled water. The slurry was heated at $0,50,60,70,80,85$ and $90^{\circ} \mathrm{C}$ in a water bath for $30 \mathrm{~min}$. After cooling to room temperature, the solution was centrifuged at $3000 \mathrm{rpm}$ for $15 \mathrm{~min}$. The supernatant was carefully recovered, and the swollen starch sediment was weighed. Aliquot of the supernatant was then evaporated overnight $\left(110^{\circ} \mathrm{C}\right)$ and swelling power and solubility were calculated from equations (3) and (4):

Swelling power $(\mathrm{g} / \mathrm{g})=\frac{\text { Weight of the wet sediment }(\mathrm{g})}{\text { Weight of the drystarch }(\mathrm{g})} \ldots \ldots \ldots \ldots$
Solubility $(\%) \quad=\quad \frac{\text { Weight of dry supernatant }(\mathrm{g})}{\text { Weight of the dry } \operatorname{starch}(\mathrm{g})} \times 100$

\section{Water Binding Capacity Determination}

Water binding capacity (WBC) was determined according to the method described by Medcalf and Gilles [18] with a few modifications. About $1.000 \mathrm{~g}$ of starch was suspended in $20 \mathrm{~cm}^{3}$ of distilled water and the suspension was agitated for 1 hour on a shaker after which it was centrifuged for $10 \mathrm{~min}$ at $2200 \mathrm{rpm}$. The supernatant was decanted and the starch deposit drained for $10 \mathrm{~min}$ and then weighed. Water binding capacity was calculated using equation (5):

WBC $(\%)=($ Weight of drained starch - Weight of the container $) \times 100$ . .5

\section{Starch Turbidity}

Starch turbidity was determined as described by Pereira and Hoover [19]. A $1 \%$ aqueous suspension of the starch sample was heated in a water bath at $90{ }^{\circ} \mathrm{C}$ for 1 hour with constant stirring. The suspension was cooled to $30{ }^{\circ} \mathrm{C}$ for 1 hour. The sample was then stored for 4 days at $4{ }^{\circ} \mathrm{C}$ and turbidity was determined every 24 hour by measuring absorbance at $640 \mathrm{~nm}$ against a water blank with a Spectrophotometer.

\section{Amylose Leaching}

Fifteen milligrammes $(15 \mathrm{mg})$ of starch sample was heated $\left(55\right.$ to $\left.85^{\circ} \mathrm{C}\right)$ in a calibrated tube for $30 \mathrm{~min}$. The tube was then cooled at ambient temperature and centrifuged at $2000 \mathrm{rpm}$ for $10 \mathrm{~min}$. The supernatant liquid $\left(1 \mathrm{~cm}^{3}\right)$ was withdrawn and amylose content was determined by the method of Chrastil [20].

\section{Statistical Analysis}

The numerical data obtained from various determinations are averages of triplicate observations. The data were subjected to statistical analysis using Minitab statistical software (Minitab Inc., USA).One-way Analysis of Variance (ANOVA) at $\alpha=0.05$ was used to compare the different mango varieties for any significant difference.

\section{Results And Discussion}

The results obtained from the analyses are presented in Tables 1 to 4 ; Figures 1 to 2 and Plates 1 to 3 .

Table 1: Proximate Analysis of Starches of Mango Varieties

\begin{tabular}{lcccc}
\hline Mango Varieties & Moisture (\%) & Ash (\%) & Protein (\%) & Lipid (\%) \\
\hline Bintasuga & $5.23 \pm 0.08$ & $0.17 \pm 0.08$ & $0.068 \pm 0.002$ & $0.23 \pm 0.03$ \\
Dankamaru & $5.30 \pm 0.10$ & $0.07 \pm 0.03$ & $0.064 \pm 0.003$ & $0.18 \pm 0.03^{\mathrm{a}}$ \\
Paparanda & $6.00 \pm 0.50$ & $0.10 \pm 0.05^{\mathrm{a}}$ & $0.069 \pm 0.003^{\mathrm{a}}$ & $0.22 \pm 0.06$ \\
Peter & $8.33 \pm 0.58^{\mathrm{a}}$ & $0.290 \pm 0.02^{\mathrm{a}}$ & $0.066 \pm 0.001^{\mathrm{a}}$ & $0.20 \pm 0.05^{\mathrm{a}}$ \\
\hline
\end{tabular}

All values are the means of triplicate determinations expressed on dry weight basis \pm standard deviation. Columns with the same superscripts are significantly different $(\mathrm{P}<0.05)$. 
Table 2: Physicochemical Properties of Starches of Mango Varieties

\begin{tabular}{lcccc}
\hline \multirow{2}{*}{\multicolumn{1}{c}{ Sample }} & \multicolumn{4}{c}{ Mango Varieties } \\
\cline { 2 - 5 } & Bintasuga & Dankamaru & Paparanda & Peter \\
\hline Starch content $(\%)$ & $59.50 \pm 1.21^{\mathrm{a}}$ & $65.37 \pm 1.11$ & $64.10 \pm 1.10$ & $52.80 \pm 1.2^{\mathrm{a}}$ \\
Amylose content $(\%)$ & $14.36 \pm 0.10$ & $16.74 \pm 0.10^{\mathrm{a}}$ & $13.36 \pm 0.40$ & $11.9 \pm 0.30^{\mathrm{a}}$ \\
Amylopectin content $(\%)$ & $85.64 \pm 0.10$ & $83.25 \pm 0.10^{\mathrm{a}}$ & $86.64 \pm 0.40$ & $90.6 \pm 0.40^{\mathrm{a}}$ \\
Swelling power $(\mathrm{g} / \mathrm{g})$ at $85^{\circ} \mathrm{C}$ & $19.40 \pm 0.30$ & $19.70 \pm 0.20$ & $19.80 \pm 0.36$ & $19.60 \pm 0.51$ \\
Solubility $(\%)$ at $85^{\circ} \mathrm{C}$ & $0.135 \pm 0.002^{\mathrm{a}}$ & $0.142 \pm 0.001$ & $0.141 \pm 0.003$ & $0.144 \pm 0.001$ \\
Water Binding Capacity $(\%)$ & $74.97 \pm 0.15^{\mathrm{a}}$ & $95.03 \pm 0.15^{\mathrm{a}}$ & $84.93 \pm 0.12^{\mathrm{a}}$ & $74.13 \pm 0.12^{\mathrm{a}}$ \\
\hline
\end{tabular}

All values are the means of triplicate determinations expressed on dry weight basis \pm standard deviation. Rows with the same superscripts are significantly different $(\mathrm{P}<0.05)$.

Table 3: Gelatinization Properties of Starches of Mango Varieties

\begin{tabular}{lcccc}
\hline Mango Varieties & $\mathbf{T}_{\mathbf{0}}\left({ }^{\mathbf{0}} \mathbf{C}\right)$ & $\mathbf{T}_{\mathbf{p}}\left({ }^{\mathbf{0}} \mathbf{C}\right)$ & $\mathbf{T}_{\mathbf{c}}\left({ }^{\mathbf{o}} \mathbf{C}\right)$ & $\mathbf{T}_{\mathbf{c}}-\mathbf{T}_{\mathbf{o}}\left({ }^{\mathbf{0}} \mathbf{C}\right)$ \\
\hline Bintasuga & $62.30 \pm 0.15$ & $66.16 \pm 0.15$ & $71.69 \pm 0.12$ & $9.39 \pm 0.85$ \\
Dankamaru & $65.50 \pm 0.10^{\mathrm{a}}$ & $65.10 \pm 0.10$ & $71.20 \pm 0.10$ & $10.70 \pm 1.02$ \\
Paparanda & $63.40 \pm 0.13$ & $68.47 \pm 0.12$ & $73.38 \pm 0.10^{\mathrm{a}}$ & $9.98 \pm 1.02$ \\
Peter & $61.5 \pm 0.05$ & $65.03 \pm 0.05$ & $70.20 \pm 0.10$ & $8.70 \pm 0.98^{\mathrm{a}}$ \\
\hline
\end{tabular}

All values are the means of triplicate determinations expressed on dry weight basis \pm standard deviation.

Columns with the same superscripts are significantly different $(\mathrm{P}<0.05)$.

Where: $T_{o}=$ onset temperature; $T_{p}=$ temperature range and $T_{c}=$ conclusion temperature

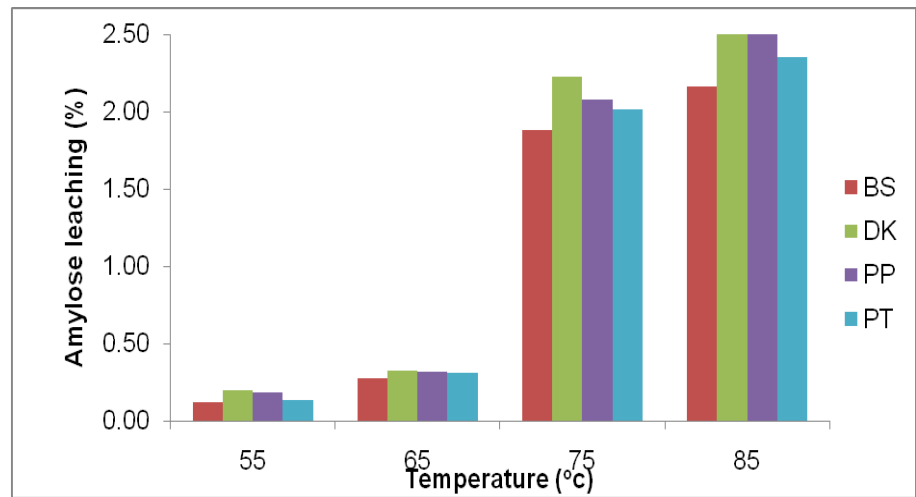

Figure 1: Amylose Leaching of the isolated starches at different temperatures.

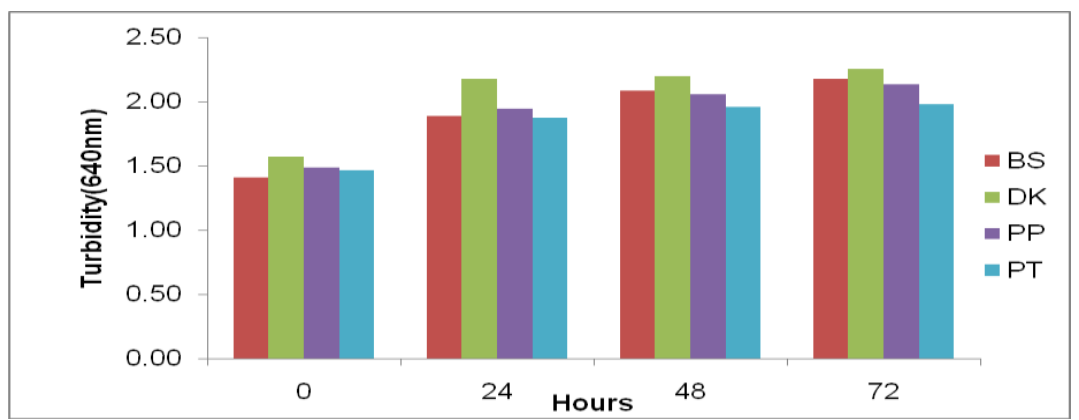

Figure 2: Turbidity of the isolated starches after 72 hours of storage. 



Plate 1: Optical micrographs of Bintasuga showing starch granular shapes at $\times 1000$ magnification.

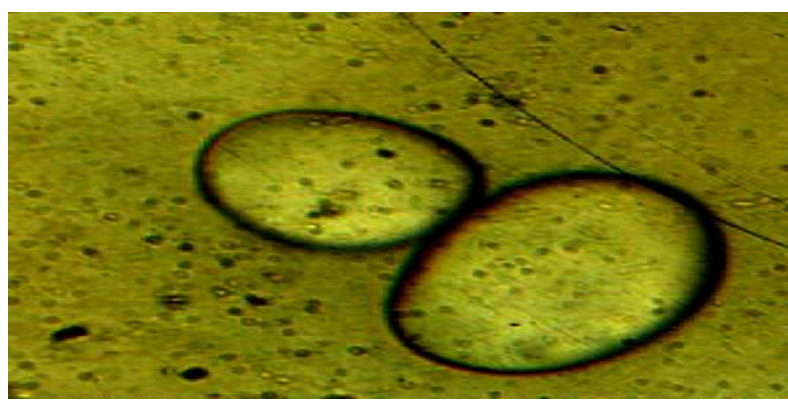

Plate 2: Optical micrographs of Dankamaru showing starch granular Shapes at $\times 1000$ magnification.

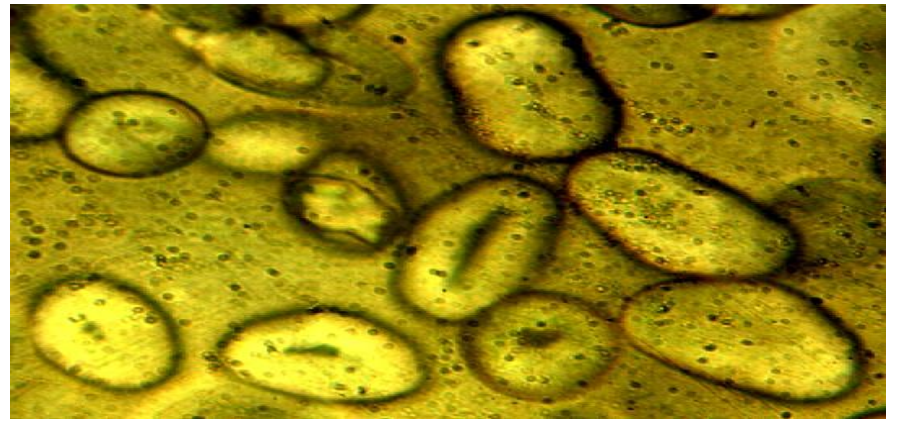

Plate 3: Optical micrographs of Paparanda showing starch Granular Shapes at $\times 1000$ magnification. 


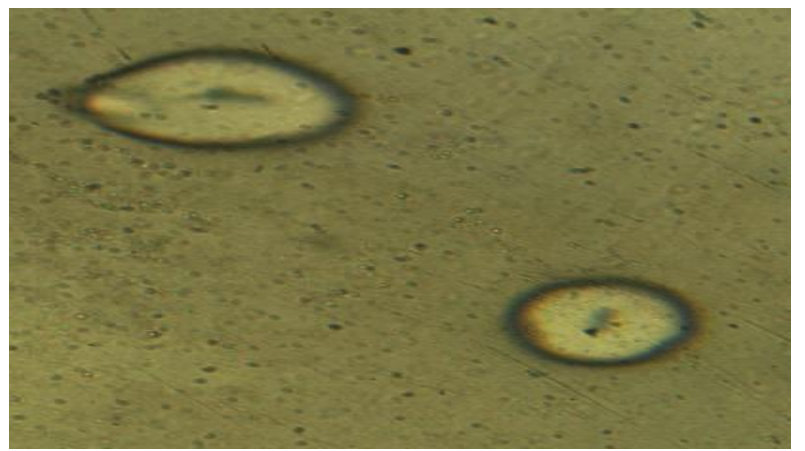

Plate 4: Optical micrographs of peter showing starch of granular shapes at $\times 1000$ magnification.

\section{Moisture Content}

The results for residual moisture content of the isolated starches were low and similar to the results of on mango starch [3]. The result showed that the moisture content of Peter starch was significantly different from those of others varieties $(\mathrm{P}=0.005, \mathrm{~F}=42.29)$. The relatively low moisture content of the starches makes them easy to store at room temperature and less prone to colonization by organism degradation as shown for root, tuber and cereal starches [21,22]; making them amenable for utilization in industries like the pharmaceutical industry that make use of low moisture content starches such as cereals starches. .

\section{Ash content}

The ash content of the starch from the four varieties mangoes were higher than the values obtained by for Mangifera indica starches [3]. However, the ash content of Dankamaru, Bintasuga and Paparanda were significantly lower than 0.20 to $0.22 \%$ for Oat starches [23]. Also, values for Peter and Bintasuga were higher than $0.14 \%$ Rye starch [24] but values for Dankamaru and Paparanda were relatively lower. The result also showed that value for Dankamaru was within the range of 0.08 to $0.09 \%$ obtained for horse grams [12]

The ash content is an estimate of the total mineral content of the starch. Even though, the values for all the starches were low, those obtained for Paparanda and Peter significantly differed from others $(\mathrm{P}=0.005$, $\mathrm{F}=42.29$ ). The low ash content is an indication of the good quality of the starches, because high mineral content are sometimes used to retard the growth of certain microorganisms [21].

\section{Starch Protein}

The results obtained were within the range of values obtained by Uba et al. [3] and Lee et al. [11]. However, they were lower than $0.09 \%$ for Rye starch [24]. Values for Paparanda and Peter also differed significantly from others $((\mathrm{P}=0.005, \mathrm{~F}=0.74)$. Low protein content is an indication of absence of endosperm protein which could affect the purity and crystallinity of the starche and as a result could adversely affect the physicochemical properties of the starches [25].

\section{Starch Lipid}

The lipid content of Dankamaru starch is significantly different from that of to Bintasuga, Paparanda and Peter $(\mathrm{P}<0.05)$. Generally, the results of the starch lipid contents of all the starches were very low (Table 1$)$ and within the range of values reported in literature $[3,11]$ but lower than the values obtained for Rye starch $(0.24 \%)$ [24]. This is an indication of low lysophospholipid contents which could also affect the purity and composition of the starch and thus make starch isolation difficult [12].

\section{Amylose Content}

The amylose content of starch determines its properties (such as water binding capacity, thickening, gelling, etc) and as a result dictates most of its uses. The results obtained showed significant variations. The amylose contents for all isolated starches were lower than values reported for mango [3] and corn starches (16.9 - 25.3) [26] but similar to amylose content of pulse starch (11.6 - 88\%) although higher than that of Oat [23]. Thus, the starch could be applied in industries that produce thickeners, binders, etc [27].

\section{Swelling Power and Solubility}

The Swelling Power $\left(\right.$ at $85^{\circ} \mathrm{C}$ ) is reported as a ratio of the volume of swollen starch granule to the volume of the dry starch Table 2. Although there was no significant difference between the swelling power of the starch from the seeds of the four varieties of mango $(\mathrm{P}>0.05)$ the values are significantly higher than 17.26 to $18.00 \mathrm{~g} / \mathrm{g}$ obtained from Horse gram starch at $85^{\circ} \mathrm{C}$ [12] but lower than those reported for rice starch [28]. The solubility on the other hand was comparable to values for Horse gram starch [12]. 


\section{Water Binding Capacity}

The water binding capacity refers to the total amount of water held by a starch gel under a defined condition [29]. The results obtained for all the starches show some variations with Dankamaru > Paparanda > Bintasuga > Peter. However, the values of the parameter from all starches were lower than those obtained from cereals, roots and tubers [22]. Water binding capacity is affected by the presence of minerals like phosphorus in starch such that starches having high phosphorus (especially cereal starches) tend to have high water binding capacity [30]. All the starches from seeds of the selected varieties of Mango had fairly good water binding capacity. Therefore, with minor modifications, could be used as substitute for cereal, root and tubers starches, since the amount of water taken up by starch is very important in food applications and in the production of super absorbent products like diapers [1].

\section{Turbidity}

The turbidity values of gelatinized starch suspensions from seeds of four varieties of mango observed that peter kernel starch paste showed lower turbidity values than other mango kernel starch pastes. The turbidity values of starch suspensions from all the seeds increased progressively during storage. The granule swelling, granule remnants, leached amylose and amylopectin chain lengths have been reported to be responsible for turbidity development in starches during storage [31]. The changes in turbidity during storage has been attributed to the interaction between leached amylose and amylopectin chains that lead to development of function zones, which might reflect or scatter a significant amount of light [19]. The turbidity value in the study did not change after $48 \mathrm{hrs}$ of storage. This may be attributed to amylose aggregation and crystallization that are completed within the first few hours of storage while amylopectin aggregation and crystallization occur during later stages [32].

\section{Gelatinization temperature}

The results in Table 3 showed that the starches have an onset gelatinization temperature ranged from 60.5 to $63.4^{\circ} \mathrm{C}$, gelatinization temperature range from 8.70 to $10.70^{\circ} \mathrm{C}$ and conclusion temperature ranged from 70.2 to $73.38^{\circ} \mathrm{C}$. The values for peter differ significantly at $(\mathrm{P}<0.05)$. These results are in agreement with the values reported for mango [3] and pulse starches [23]. The gelatinization property of starch is a determining factor in its functionality in food applications [33].

\section{Starch Granules}

The optical micrographs in Plates 1 to 4 show the presence of starch granules which are oval in shapes. The starch granules of the selected varieties of mango seeds compare well with the result of Uba et al. [3] and were observed to be similar to legume starch granule but different from corn, rice, wheat and potatoes starch granules.

\section{Amylose Leaching}

The disruption of starch structure during heating results into release of amylose into the solution a process called amylose leaching. The amount of amylose can be quantified and it gives an insight into the behaviour of starch during heating. Increasing temperature results into high proportions of leached amylose ([34]. Dankamaru and paparanda showed high amylose leaching, whereas peter gave the lowest. This shows that the stability of the structure in these starches is almost the same with the exception of peter, making them applicable for the same functions.

\section{Conclusion}

This study has shown that all the selected varieties of mango seeds (Bintasuga, Dankamaru, Paparanda, and Peter) contained significant amounts of starch. The study also shows that the starches from the four varieties exhibited differences in properties such as starch content, amylose, water binding capacity, and gelatinization properties. Specifically, in some instances, Dankamaru starch exhibited better properties over others. Thus even though there are significant differences in some of the properties of the starches from the selected varieties of mango, the starches showed good properties and could serve as alternatives for the production of industrial products. 


\section{References}

[1] Madigan, E. (2003). New Uses for Starch. HealthGuidance for Better Health. Retrieved on 20/1/2011 from: http://www.healthguidance.org/pages/Terms-of-Service.

[2] John, S. G. (2010). Starch - The Booming Industry. Science Tech Entrepreneur, December, 2010. Retrieved February, 3 , 2011 from: http://www.wisconsinpotatoes.com/_PDF/TeachersInfo/Starchsources.pdf.

[3] Uba, A., Izuagie, T., Hassan, L. G., Achor, M. and Sahabi, D. M. (2011a). Charaterization of starch isolated from Mangifera indica seeds. Nigerian Journal of Basic and Applied Science, 19 (2): 224-230.

[4] Uba, A., Izuagie, T., Hassan, L. G., Achor, M. and Sahabi, D. M. (2011b). Physicochemical Properties of Starch Isolated from Seeds of Chrysophyllum albidum. International Journal of Chemical Sciences. 4(21): $264-270$.

[5] Raemakers, R. H. (2001). Crop Production in Tropical Africa: Directorate General for International Cooperation (D.G.I.C), Brussels, Belgium. Pp. 596-609.

[6] FAO (2002). Food and Agriculture Organisation of the United Nations Statistics (FOASTAT) database-agriculture, Rome, Italy. Retrieved on 23/04/2012 from: Available www.fao.org.

[7] Watson, A. J. (1983); Agricultural innovation in the early Islamic world: the diffusion of crops and farming techniques, 700-1100. Cambridge, UK: Cambridge University Press. pp. 72-3.

[8] Jedele, S. Hau, A.M. and von, O. M. (2003); An Analysis of the World Market for Mangoes and its importance for developing countries. Conference on International Agricultural Research for Development, held on $8-10^{\text {th }}$ October at University of Göttingen, Deutscher Tropentag, Germany.

[9] Ezeagu, I. E., Metges, C. C., Proll, J. Petzke, K. J. and Akinsoyinu, A. O. (2011). Chemical Composition and Nutritive Value of Some Wild-Gathered Tropical Plant Seeds. Retrieved on February 3, 2010 from:http//:www.chemcommandnutrient.

[10] Kaur, L. J., Sing, and Q. Liu, (2007)."Starch a Potential Biomaterial for Biomedical Applications" Nanometer, Nanosyst., Biomed., Appl., p. 83.

[11] Lee, H. C., Htoon, A. K. and Paterson, J. L. (2007). Alkaline Extraction of Starch from Australian Lentil Cultivars: Matilda and Digger Optimised for Starch Yield and Starch and Protein Quality. Food Chemistry, 102: 551-559.

[12] Chavan U. D., Shinde B.G., Kadam, S. S., and Amarowicz, A. (2010). Isolation and Characterization of Starch from Horse Gram. African Journal of Food Science and Technology, 1(3): $64-67$.

[13] AOAC (1990). Association of Official Analytical Chemists. Official Methods of Analysis. 12th ed. Washington, DC

[14] Williams, P.C., Kurzina, F. D., and Hlynka, I. (1970). A rapid colorimetric procedure for estimating the amylase content. Cereal Chemistry, 47: 411-420.

[15] General Tests (2011); Powder Particle Size Determination. JP XIV. $77 \quad-\quad 78$. $\quad$ retrived on $3 / 7 / 2011$ from:www.malvern.com/ParticleSizeAnalysis.

[16] Linus, A. J. (1995); Tableting Behavior of Some Depolymerise Local Starches. An M.Sc (Pharmaceutics) Dissertation, Ahmadu Bello University Zaria, Nigeria, Pp $42-45$.

[17] Nadiha, M. Z. N., Fazilah, A., Bhat, R. and Karim, K. A. (2010); Comparative Susceptibilities of Sago, Potato and Corn Starches to Alkali Treatment. Food Chemistry, (121): 1053-1059.

[18] Medcalf, D. G. and Gilles, K. A.(1965).Wheat Starches I: Comparison of physicochemical properties. Cereal Chemistry, 42, 558568.

[19] Pereira, C. and Hoover, R. (1999). Influence of Hydroxypropylation on Retrogradation Properties of Native, Defatted and Heatmoisture Treated Potato Starches. Food Chemistry, 64: 361-375.

[20] Chrastil, J. (1987). Improved Colorimetric Determination of Amylose in Starches of Flours. Carbohydrate Research, 159: 154-158.

[21] Nielsen, S. S. (1998). Food Analysis, $2^{\text {nd }}$ Edition. Aspon publication, Gaithersberge, Maryland, Pp. 40 - 250.

[22] Nuwamanya, E., Baguna, Y., Wembabazi, E., and Rubaihayo, P., (2011). A Comparative Study of the Physicochemical Properties of Starches from Root, Tuber, and Cereal Crops. African Journal of Biotechnology, Vol. 10(56), Pp 12018 - 12030.

[23] Hoover, R., Hughes, T., Chung, H. J. and Liu, Q. (2010). Composition, Molecular Structure, Properties, and Modification of Pulse Starches: A review. Food Research International. 43, 399-413

[24] Verwimp, T., Vandeputte, G.E., Marrant, K. and Delcuor, J. A (2004); Isolation and Characterisation of Rye Starch. Journal of Cereal Sciences. 39: 85, - 90.

[25] Tester, R.F., and Morrison, W.R. (1990). Swelling and Gelatinization of Cereal Starches. Effect of Amylopectin. Amylose and Lipids. Cereals Chemistry. 67: $551-557$.

[26] Sandhu, K.S and Singh, N. (2007). Some Properties of Corn Starches II: Physicochemical, Gelatinization, Retrogradation, Pasting and Gel Textural Properties. Food chemistry, 101: 1499 - 1507.

[27] Yuan, Y., Zhang, L., Dai, Y. and Yu, J. (2007); Physicochemical Properties of Starch obtained from Discorea nipponica Makino Comparison with Other Tuber Starches. Journal of Food Engineering. 82:436 - 442..

[28] Singh, N., Singh, J., Kaur, L., Sodhi, N.S. and Gill, B.S. (2003). Morphological, Thermal, and Rheological Properties of Starches from Different Botanical Sources: A Review. Food Chemistry, 81, 219-231.

[29] Pinnavaia G. and Pizzirani S. (1998). Evaluation of the Degree of Gelatinization of Starchy Products by Water Holding Capacity. Starch/Stärke, 50 (2-3): 64-67.

[30] Zuluaga M, Baena Y, Mora C, Ponce D’León L (2007). Physicochemical Characterization and Application of Yam (Dioscorea cayenensisrotundata) Starch as a Pharmaceutical Excipient. Starch/Stärke. 59: 307-317.

[31] Jacobson, M. R., Obanni, M., and BeMiller, J. N. (1997). Retrogradation of Starches from Different Botanical Sources. Cereal Chemistry, 74, 571-578.

[32] Miles, M. J., Morris, V. J., Orford, R. D., and Ring, S. G. (1985). The Roles of Amylose and Amylopectin in the gelatinization and retrogradation of starch. Carbohydrate Research, 135: 271-281.

[33] Evans, J. D. and Haismann, D. R. (1982). The effect of solutes on the Gelatinization Temperature of Potato starch. Starch/Staerke, 34: $224-231$.

[34] Palav T, and Seetharaman K (2006). Mechanism of Starch Gelatinization and Polymer Leaching during Microwave Heating, Carbohydrate Polymers.65(3): 364-370. 